\title{
Architektura informacji jako dyscyplina akademicka \\ (Kraków, 5-6 czerwca 2018 r.)
}

W dniach 5-6 czerwca 2018 r. w Krakowie odbyła się międzynarodowa konferencja naukowa pod nazwą „Architektura informacji jako dyscyplina akademicka” (AIDA). Organizatorem konferencji był Instytut Nauk o Informacji Uniwersytetu Pedagogicznego w Krakowie przy współpracy z Polskim Towarzystwem Informacji Naukowej. Konferencja w założeniu była adresowana do przedstawicieli ośrodków akademickich w Polsce, w których prowadzi się kierunki studiów związane z architekturą informacji (AI). Głównym celem organizatorów miało być udostępnienie forum wymiany doświadczeń w zakresie kształcenia w Polsce architektury informacji na poziomie akademickim.

Tematyka konferencji wpisuje się w problematykę zmian w ofercie dydaktycznej polskich ośrodków akademickich kształcących dotychczas na kierunkach związanych z informatologią i bibliologią. Zjawisko to dotyczy niemal wszystkich polskich ośrodków. Architektura informacji jest jednym z nowych kierunków studiów, które sukcesywnie od kilku lat są wprowadzane do oferty tych ośrodków. To właśnie Instytut Nauk o Informacji Uniwersytetu Pedagogicznego w Krakowie w 2013 r., jeszcze pod nazwą Instytut Informacji Naukowej i Bibliotekoznawstwa, jako pierwszy wprowadził ten kierunek do swojej oferty dydaktycznej. Przez kolejne lata kierunek ten był włączany do oferty kolejnych jednostek: Instytutu Informacji Naukowej i Bibliotekoznawstwa UMCS, Instytutu Informacji Naukowej i Bibliologii UMK, a od roku akademickiego 2018/2019 znalazł się również w ofercie Instytutu Bibliotekoznawstwa i Informacji Naukowej UŚ oraz Wydziału Dziennikarstwa, Informacji i Bibliologii UW. Próba określenia statusu architektury informacji jako dyscypliny akademickiej wydaje się więc być nie tyle ciekawym zagadnieniem, co nawet koniecznością zarówno z punktu widzenia jakości kształcenia, jak i określenia związków AI z bibliologią i informatologią. Celem konferencji AIDA była więc dyskusja na temat treści programowych, metod dydaktycznych oraz tożsamości architektury informacji jako dyscypliny akademickiej. Wypracowanie wspólnych ram interpretacyjnych uwzględniających teorie, metodologie i epistemologie AI jest o tyle istotne, że architektura informacji jest kojarzona głównie z działalnością praktyczną, a bez podbudowy teoretycznej trudno nadać jej status kierunku akademickiego.

Obrady konferencji zorganizowano w 10 sesjach tematycznych:

(1) Sesja plenarna: Światowe trendy w architekturze informacji (ang. The World Trends of Information Architecture)

(2) Kierunki badań w zakresie architektury informacji jako dyscypliny akademickiej (ang. Directions of Information Architecture development as an academic discipline)

(3) Problemy badawcze architektury informacji

(4) Metody badań AI

(5) Praktyczne zastosowania AI

(6) Kształcenie architektów informacji: oferta edukacyjna

(7) Wybrane problemy dydaktyki AI

(8) Problemy projektowania środowisk informacyjnych

(9) Kompetencje absolwentów a oczekiwania pracodawców

(10) Inspiracje: przegląd studenckich projektów.

Głównym językiem wystąpień był język polski. Tylko w przypadku pierwszych dwóch sesji referaty wygłoszono w języku angielskim. 
Do udziału w sesji plenarnej zaproszono Petera Morville’a - jednego z twórców koncepcji architektury informacji, oraz Andreę Resminiego - redaktora naczelnego i współzałożyciela czasopisma naukowego Journal of Information Architecture.

Podczas wystąpienia otwierającego konferencję, P. Morville przedstawił genezę i rozwój architektury informacji od lat 90. ubiegłego wieku, skupiając się przede wszystkim na jej związkach z innymi dyscyplinami naukowymi i sferami życia człowieka oraz ich wzajemnym oddziaływaniu na siebie. Autor przekonywał, że projektując systemy i usługi informacyjne, należy poświęcać uwagę nie tylko potrzebom informacyjnym użytkownika, ale również uwarunkowaniom kulturowym, politycznym i środowiskowym, w których on funkcjonuje. P. Morville przedstawił ewolucję koncepcji architektury informacji z punktu widzenia ekologii informacji. Autor dużo uwagi poświęcił pojęciu planowania $\mathrm{w}$ odniesieniu do projektowania usług informacyjnych.

Andrea Resmini w swoim referacie odniósł się do roli architektów informacji w kształtowaniu przestrzeni cyfrowych ze szczególnym uwzględnieniem odpowiedzialności, jaką niesie ze sobą budowanie relacji człowiek - komputer. Przywołując definicję świata po rewolucji cyfrowej, A. Resmini pokazał jak wiele codziennych sytuacji, z którymi ma do czynienia człowiek przeniosło się do rzeczywistości cyfrowej. Porównując dawnych architektów i urbanistów do architektów informacji, zaprezentował, w jaki sposób decyzje podejmowane przez nich kształtują procesy komunikacji w sieci.

W drugiej sesji poświęconej rozwojowi architektury informacji jako dyscyplinie akademickiej wygłoszono cztery referaty. Stanisław Skórka (UP) podjął próbę charakterystyki paradygmatu architektury informacji, przedstawiając założenia tej dziedziny. Autor podkreślił również jej multidyscyplinarny charakter, który znacząco wpływa na postrzeganie pola badawczego AI. Marcin Roszkowski (UW) wygłosił referat na temat roli interpretacji i rozumienia w projektowaniu i badaniu usług informacyjnych. Punktem wyjścia jego rozważań była koncepcja cyfrowej hermeneutyki oraz poszukiwanie ujęcia interpretatywnego w badaniach nad organizacją wiedzy i w dziedzinie interakcji człowiek-komputer. Celem wystąpienia Zbigniewa Osińskiego (UMCS) było zwrócenie uwagi na charakter efektów kształcenia w ramach kierunku AI, który zdaniem prelegenta powinien uwzględniać większą rolę nabywania umiejętności praktycznych przez absolwentów. Autor przedstawił swoje wnioski na przykładzie doświadczeń z realizacji kursu dotyczącego wizualizacji informacji. Barbara Kamińska-Czubała (UP) podjęła problem badań użytkowników w odniesieniu do koncepcji AI. Autorka omówiła poszczególne techniki badawcze w kontekście możliwości ich zastosowania w projektach związanych z AI. Tematem wystąpienia Michała Rogoża (UP) była ochrona własności intelektualnej w kształceniu architektów informacji. Prelegent przedstawił wyniki analiz na temat obecności tych treści programowych w wybranych kursach obecnych w programach studiów.

W sesji poświęconej problemom badawczym AI wygłoszono cztery referaty. Jako pierwszy zabrał głos Piotr Marcinkowski reprezentujący firmę Aleph, która była jednym ze sponsorów konferencji. Prelegent przedstawił elementy architektury informacji nowego interfejsu systemu Primo, koncentrując się na aspektach związanych z funkcjonalnością i użytecznością. Wiesław Babik (UJ) podjął próbę konfrontacji założeń języka słów kluczowych z metodyką architektury informacji, zwracając uwagę na rolę tagów i społecznościowego katalogowania. Jacek Tomaszczyk (UŚ) w swoim wystąpieniu wskazał na ważny problem spójności terminologicznej AI ze szczególnym uwzględnieniem przejmowania angielskich terminów do polskiej terminologii AI. Autor, na wybranych przykładach, pokazał konieczność prowadzenia prac badawczych w celu uporządkowania terminologii AI. Hanna Batorowska (UP), w ostatnim wystąpieniu w tej sesji, przedstawiła wyniki badań na temat kształcenia umiejętności myślenia analityczno-syntetycznego w odniesieniu do procesów klasyfikowania, kategoryzowania i streszczania dokumentów przez studentów. Tego typu kompetencje mają istotne znaczenie w aktywności zawodowej w ramach AI i zarządzania informacją. Autorka wskazała na rozbieżności w samoocenie studentów na temat poziomu tych kompetencji a rzeczywistymi wynikami, które osiągali.

W pierwszym dniu konferencji odbyły się jeszcze trzy sesje tematyczne poświęcone: (1) metodom badań nad AI, (2) praktycznym zastosowaniom AI oraz (3) kształceniu w zakresie AI. Z uwagi na 
fakt, że były to sesje równoległe, w dalszej części zostaną omówione wybrane wystąpienia. Z punktu widzenia celów konferencji szczególne znaczenie miała wymiana doświadczeń w zakresie kształcenia AI, co miało miejsce w przypadku sesji pt. „Kształcenie architektów informacji: oferta edukacyjna”. Podczas tej części konferencji przedstawiciele ośrodków z UMCS, UMK, UŁ oraz UŚ prezentowali założenia oraz doświadczenia związane z AI jako kierunkiem studiów. Prezentacje dotyczyły co prawda różnych aspektów związanych z kształceniem w ramach AI, ale sesja ta dała możliwość porównania koncepcji kształcenia AI w ujęciu informatologicznym.

Drugiego dnia konferencji odbyły się cztery sesje tematyczne, z czego pierwsze dwie zorganizowano równolegle. W dalszej części zostaną omówione wybrane wystąpienia.

Referaty zaprezentowane w sesji pt. „Wybrane problemy dydaktyki AI” poruszały przede wszystkim zagadnienia szczegółowe związane z kształceniem w zakresie AI. Hanna Gaweł (UJ) omówiła problem kształcenia w zakresie analizy i wizualizacji danych, skupiając się na aspektach technicznych. Przemysław Paliwoda (UP) poruszył ten sam problem, ale z punktu widzenia kształtowania kompetencji studentów, w których istotna jest równowaga między umiejętnościami statystycznymi oraz wiedzą z zakresu estetyki. Autor przedstawił efekty swojej pracy ze studentami na zajęciach poświęconych architekturze informacji i wizualnej reprezentacji danych. Formy zaprezentowane przez studentów podczas zajęć zdecydowanie odbiegały od tradycyjnego postrzegania wizualizacji danych za pomocą wykresów, nawiązując do sztuki plakatu i abstrakcji. Marta Czusz (UW) podjęła się porównania programów nauczania na kierunku AI w polskich ośrodkach akademickich kształcących w zakresie bibliologii i informatologii. Autorka dokonała kategoryzacji przedmiotów na podstawie trzech głównych obszarów badawczych AI - użytkownik, zawartość, kontekst. Opracowane w ten sposób analizy dały możliwość utworzenia dosyć ogólnych profilów poszczególnych programów kształcenia. W ostatnim referacie w tej sesji Beata Langer (UP) podzieliła się doświadczeniami na temat efektowności nauczania treści programowych z zakresu nauki o informacji na kierunku architektura informacji.

Ciekawym uzupełnieniem dyskusji o kształceniu w zakresie AI była sesja poświęcona przeglądowi projektów studenckich. Ewa Leś (UP) zaprezentowała wyniki autorskiego projektu, którego celem było stworzenie planu tematycznej trasy rowerowej w Krakowie. Prelegentka zaprezentowała propozycje spójnej identyfikacji wizualnej, pokazując jednocześnie, że przedmiotem architektury informacji nie są jedynie systemy informacyjne, ale również obiekty ze świata rzeczywistego. Wiktoria Jamróz (UP) wygłosiła referat przedstawiający wyniki badań prowadzonych w ramach pracy licencjackiej na temat związków architektury informacji z neuroestetyką. Za pomocą techniki eyetrackingowej autorka zbadała sposoby postrzegania wizualnych reprezentacji informacji w postaci plakatu przez użytkowników. Sesja przeznaczona dla studentów zakończyła się wyróżnieniem zgłoszonych plakatów i infografik, które prezentowały zagadnienia związane z architekturą informacji.

Ostatnia sesja została poświęcona kompetencjom absolwentów kierunków związanych z AI oraz oczekiwaniom pracodawców. Ewa Głowacka (UMK) przedstawiła wyniki badań prowadzonych wraz z Małgorzatą Kisilowską (UW) oraz Magdaleną Paul (UW), które dotyczyły samooceny kompetencji informacyjnych studentów kierunków informatologicznych, historii i dziennikarstwa. Julia Hladiy (UMK) poruszyła problem poziomu wiedzy pracodawców na temat AI. Autorka przeprowadziła ankietę wśród potencjalnych pracodawców absolwentów AI. W wyniku przeprowadzonych badań autorka uzyskała dosyć niepokojący obraz niskiej świadomości potencjalnych pracodawców na temat tego czym zajmuje się AI oraz jakie kompetencje ma architekt informacji. Podczas ostatniego referatu wygłoszonego na konferencji Małgorzata Lebda (UP) przedstawiła swoje doświadczenia w pracy ze studentami nad projektami fotograficznymi. Skupiając się na zagadnieniu visual literacy (kompetencje wizualne), prelegentka przekonywała o roli umiejętności odczytywania i interpretowania komunikatów wizualnych w kontekście kształcenia w ramach architektury informacji.

Podczas dwóch dni obrad wygłoszono ponad 40 referatów, których tematyka wpisywała się w problematykę obecności architektury informacji w kształceniu akademickim w Polsce. Dużą wartością 
konferencji była możliwość przyjrzenia się różnym koncepcjom kształcenia AI oraz dyskusji nad treściami programowymi. Szczególnie istotne, z punktu widzenia kształcenia AI na poziomie akademickim, wydaje się być określenie jej związków z informatologią oraz praca nad uporządkowaniem warstwy teoretycznej, metodologicznej i terminologicznej architektury informacji.

Marcin Roszkowski

Katedra Informatologii

Wydziat Dziennikarstwa, Informacji i Bibliologii

Uniwersytet Warszawski

Patryk Hubar

Wydziat Dziennikarstwa, Informacji i Bibliologii

Uniwersytet Warszawski

Nadestano: 16 lipca 2018 